\title{
PROPAGATION OF SOME HARD-TO-ROOT ORNAMENTAL PLANTS BY TISSUE CULTURE II - ESTABLISHMENT AND MULTIPLICATION
}

Mahmoud El Sayed Hashem; Faisal Mohamed Saadawy ${ }^{2}$; Salah AbdelAziz Gomaa ${ }^{2}$ and Nermeen El-Sayed Abdul-Moneem ${ }^{2}$

1- Dept. of Horticulture, Faculty of Agriculture, Ain Shams University, Shoubra ElKhema, Cairo, Egypt.

2- Dept. of Ornamental Plant Researches, Horticulture Research Institute, Agriculture Research Center, Giza, Egypt.

ABSTRACT

Applying benzyladenine (BA) at 1 or $2 \mathrm{ppm}$ to the culture medium at the establishment stage, proved to have a significant effect in increasing survival percentage of Cupressus macrocarpa explants. On the other hand, survival percentage of Conocarpus explants was not significantly influenced by the presence or absence of BA. The use of BA resulted also in the highest multiplication rates of both Cupressus macrocarpa and Conocarpus erectus, though the effect was insignificant with the first species. Leaving a heel on the explant of Conocarpus erectus showed significantly a superior effect in increasing shoot number, shoot fresh weight and leaf number.

At the multiplication stage, the highest number of shoots resulted by using BA at 2 and 4 ppm for Cupressus macrocarpa and Conocarpus erectus, respectively. The highest contents of total chlorophyll and carotenoids of Cupressus macrocarpa shoots were those induced by applying kinetin at $6 \mathrm{ppm}$. Application of BA at 6 ppm to the culture medium was associated with a greater increase in these contents in the case of Conocarpus erectus.

Key Words: Cupressus macrocarpa, Conocarpus erectus, Tissue culture, Benzyladenine, Kinetin, Establishment, Multiplication.

\section{INTRODUCTION}

Propagation by stem cuttings is the most important method of propagating either deciduous as well as broad- and narrow-leaved types of ornamental shrubs and trees. Unfortunately, cuttings of many plants such as Cupressus macrocarpa Hartw. ex Gord. and Conocarpus erectus L. are somewhat calcitrant. They do not root easily or even do not root at all. Many approaches have been adopted to overcome this obstacle. Tissue culture technique represents a promising means to solve this problem.

Cytokinins in tissue culture techniques are highly recommended in order to induce proliferation and organ regeneration. Franco and Schwarz (1985) remarked that when cotyledon explants from Pinus oocarpa and hypocotyl explants from Cupressus lusitanica were cultured on nutrient medium with various cytokinins, adventitious buds were induced. Lambardi et al (1995) mentioned that adventitious buds of Cupressus sempervirens were formed on excised mature embryos cultured on half-strength Quoirin and Lepoivre medium $(1 / 2 \mathrm{QP})$ with $10 \mu \mathrm{M}(2.25 \mathrm{ppm}) \mathrm{BA}$. Capuana and Giannini (1997) stated that bud induction of Cupressus sempervirens explants was realized on SH medium containing $1.12 \mathrm{ppm}$ BA (and $0.02 \mathrm{ppm}$ NAA). Ponchia and Zanin (2000)

Fayoum J. Agric. Res. \& Dev., Vol.19, No.1, January, 2005 
reported that high proliferation of shoots of the male clone of Skimmia japonica (Fam. Rutaceae) was achieved in MS medium with BA at $8.9 \mu \mathrm{M}(2 \mathrm{ppm})$. GenLin et al (2003) remarked that BA was found to be suitable for the multiplication of adventitious shoots of Ilex latifolia (Fam. Aquifoliaceae) from nodal segments. Mishra and Sreenath (2003) mentioned that among the various growth regulators evaluated, BA was the most effective in the induction of shoot buds of Coffea bengalensis (Fam. Rubiaceae). Silva et al (2003a) cultured shoot apices and lateral buds of 3 rootstocks of Prunus on Lepoivre medium supplemented with $5.0 \mathrm{mg}$ BAP /litre. They stated that explant survival rates averaged $62.9 \%$ and $58.8 \%$ for shoot apices and lateral buds, respectively. Yonemitsu et al (2003) reported that shoot proliferation of Japanese apricot (Prunus mume) in subcultures was best in WP agar medium containing $4.4 \mu \mathrm{M}$ (1 ppm) BA. Zhu et al (2003) showed that multiplication rate of the apple rootstock M26 increased with the increase in the concentration of benzyladenine (and IBA) in the multiplication medium. Similar results were obtained with the addition of kinetin. Isutsa (2004) proliferated yellow passion fruit (Passiflora edulis var. flavicarpa, Fam. Passifloraceae) on a medium containing $22.2 \mu \mathrm{M}$ (5 ppm) BAP.

However, in some cases the presence of any kind of a cytokinin was not necessary, while failure of cytokinins to induce proliferation was reported in other ones. Lambardi et al (1995) stated that axillary shoot formation of Cupressus sempervirens occurred spontaneously as adventitious shoots aged and transfer intervals were increased. Spanos et al (1997) mentioned that proliferation of axillary shoots of Cupressus sempervirens occurred without addition of benzyladenine, although a significant increase in number of shoots resulted on addition of up to $1.0 \mathrm{mg}$ benzyladenine/litre. The aim of this study was to establish an applicable protocol for the rapid micropropagation of two ornamental plant species important for landscaping purposes and belonging to different genera,i.e. Cupressus macrocarpa and Conocarpus erectus.

\section{MATERIALS AND METHODS}

This work was carried out in the Tissue Culture Laboratory of Pomology, Horticulture Department, Faculty of Agriculture, Ain Shams University through three successive years (2001-2004).

Two types of cytokinins, incorporated in the media, were used. These were benzyladenine (6-benzylaminopurine), referred to for short in the references as $\mathrm{BA}$ or BAP, and kinetin (6-furfuryl aminopurine), referred to for short as KI or Kin.

\section{Establishement Stage:}

New young lateral shoots of Cupressus macrocarpa and lateral buds of Conocarpus erectus were excised and surface-sterilized by $\mathrm{MC}\left(\mathrm{HgCl}_{2}\right)$ at 500 ppm for $6 \mathrm{~min}$. These explants were established for four weeks on Murashige and Skoog (1962) medium (MS) under aseptic conditions using a laminar airflow cabinet. The tubes $\left(15 \times 1.5 \mathrm{~cm}\right.$, i.e. $20 \mathrm{ml}$, filled with about $10 \mathrm{~cm}^{3}$ of the medium and closed by aluminum foil shaped as caps) were incubated at $25 / 20^{\circ} \mathrm{C}$ (day/night) $\pm 2^{\circ} \mathrm{C}, 70 \%$ relative humidity. Two fluorescent tubes/shelf were installed at $30 \mathrm{~cm}$ above explants to provide light intensity of 2200-2400 lux at explant level for $16 \mathrm{~h}$. daily. The establishment medium was supplemented with one of the following concentrations (treatments) of BA $(0,1$ and $2 \mathrm{ppm})$ in

Fayoum J. Agric. Res. \& Dev., Vol.19, No.1, January, 2005 
a completely randomized experiment. Each treatment comprised four replicates. Each replicate contained six tubes. Data obtained were survival percentage and multiplication rate (MR), i.e.:

$M R=\frac{\text { No. of shoots produced within four weeks }}{\text { No. of original shoots inoculated }}$

No. of original shoots inoculated

\section{Effect of a heel on explant establishment (in Conocarpus erectus only):}

It was noticed that leaving a part of the older branch tissue (a heel of about 2 mm long) on the excised explant made some difference compared with a clearcut explant in respect of survival percentage and multiplication rate. Therefore, a completely randomized experiment was laid out to assess the difference between the two options, with or without a heel. Each treatment comprised of four replicates. Each replicate contained six tubes. Data obtained in this experiment were survival percentage and multiplication rate of explants. Inoculation and incubation was performed as mentioned in the establishment stage. Data recorded for this experiment were shoot number, length and fresh weight and leaf number.

\section{Multiplication Stage:}

Small pieces ( $5 \mathrm{~mm}$ long) taken from the terminal part of in vitro produced shoot explants of Cupressus macrocarpa and nodal buds of Conocarpus erectus obtained from in vitro produced shoots were used.

a. Cupressus macrocarpa

A completely randomized experiment in a factorial design was carried out to study two factors affecting multiplication process, i.e. the type of cytokinin (as a main plot) and the concentration used (as a sub-plot). The two cytokinins used were BA and Kin. As the response observed in establishment stage to the cytokinin-free media was very low, only three concentrations of each type of the two cytokinins were used, i.e. 2,4 and $6 \mathrm{ppm}$. No cytokinin-free treatment was included. Each treatment comprised 4 replicates, with 6 tubes in every replicate.

b. Conocarpus erectus

Kinetin treatment was discarded, as preliminary trials of Conocarpus erectus explants gave no response to it. Accordingly, this experiment was confined to $\mathrm{BA}$ only, at 2, 4 and $6 \mathrm{ppm}$ in a completely randomized experiment. Each treatment comprised 4 replicates, with 6 tubes in each replicate.

Data obtained one month later were number, length and fresh weight of shoots, total leaf number in addition to total chlorophyll and carotenoids determination (as $\mathrm{mg} / \mathrm{g}$ fresh weight of shoots).

Data of these experiments were statistically analyzed using SAS 1995 computer program, and means were compared by L. S. D. method, and all percentages were transformed according to Snedecor and Cochran (1980).

\section{RESULTS AND DISCUSSION}

Experiment 1. Effect of BA during the establishment stage:

1 - Effect of BA concentration on explants survival percentage.

a - Cupressus macrocarpa (Table 1-a)

Applying BA either at 1 or $2 \mathrm{ppm}$ proved to have a significant effect in increasing survival percentage of explants as shown in (Table 1-a). The presence of BA in the media, at both concentrations resulted in $90 \%$ survival percentage.

Fayoum J. Agric. Res. \& Dev., Vol.19, No.1, January, 2005 
The corresponding percentage in media deprived of BA was 59.04\%, significantly lower than that mentioned before.

Table (1-a) Effect of BA concentration on explants survival\% a- Cupressus macrocarpa

\begin{tabular}{cc}
\hline BA concentration & Survival \% \\
\hline $0 \mathrm{ppm}$ & $59.04 \mathrm{~b}$ \\
$1 \mathrm{ppm}$ & $90.00 \mathrm{a}$ \\
$2 \mathrm{ppm}$ & $90.00 \mathrm{a}$ \\
\hline LSD at $5 \%$ & 24.25 \\
\hline
\end{tabular}

b-Conocarpus erectus (Table 1-b)

Survival percentage of Conocarpus explants was not significantly influenced by the presence or absence of BA. All treatments, including that free of BA, resulted in $90 \%$ survival.

Table (1-b) Effect of BA concentration on explants survival \% b- Conocarpus erectus

\begin{tabular}{cc}
\hline BA concentration & Survival \% \\
\hline $0 \mathrm{ppm}$ & $90.00 \mathrm{a}$ \\
$1 \mathrm{ppm}$ & $90.00 \mathrm{a}$ \\
$2 \mathrm{ppm}$ & $90.00 \mathrm{a}$ \\
\hline LSD at 5\% & N.S. \\
\hline
\end{tabular}

2 - Effect of BA concentration on multiplication rate.

a-Cupressus macrocarpa (Table 2-a)

The effect of BA concentrations on multiplication rate of Cupressus was insignificant. Although this rate was high by using BA at $2 \mathrm{ppm}$, the difference between this record and the lowest one (1.34) by using BA at 1 ppm was insignificant.

Table (2-a) Effect of BA concentration on multiplication rate of Cupressus macrocarpa

\begin{tabular}{cc}
\hline BA concentration & Multiplication rate \\
\hline $0 \mathrm{ppm}$ & $1.38 \mathrm{a}$ \\
$1 \mathrm{ppm}$ & $1.34 \mathrm{a}$ \\
$2 \mathrm{ppm}$ & $1.58 \mathrm{a}$ \\
\hline LSD at $5 \%$ & N.S. S. \\
\hline
\end{tabular}

$\mathrm{b}$ - Conocarpus erectus (Table 2-b)

Multiplication rate of Conocarpus was 2.38 as a result of using BA at 2 ppm. This was significantly higher than rates occurred by using BA at 0 or $1 \mathrm{ppm}$ ( 0.17 and 0.50 respectively), without significant difference between the last two records.

Table (2-b) Effect of BA concentration on multiplication rate of Conocarpus erectus

\begin{tabular}{cc}
\hline BA concentration & Multiplication rate \\
\hline $0 \mathrm{ppm}$ & $0.17 \mathrm{~b}$ \\
$1 \mathrm{ppm}$ & $0.50 \mathrm{~b}$ \\
$2 \mathrm{ppm}$ & $2.38 \mathrm{a}$ \\
\hline LSD at $5 \%$ & 0.43 \\
\hline
\end{tabular}

Fayoum J. Agric. Res. \& Dev., Vol.19, No.1, January, 2005 
Concerning culture initiation or the establishment stage, Meghwal et al (2003) remarked that woody plant medium (WPM) supplemented with $2 \mathrm{mg}$ $\mathrm{BA} /$ litre was the best medium for culture initiation of nodal explant of the Aneuploid No. 82, an important dwarfing rootstock for guava. MeiChun (2003) reported that modified MS medium supplemented with $2 \mathrm{mg} / \mathrm{l}$ benzyladenine resulted in a maximum rate of shoot proliferation (average of 6.5 shoots/explant in 40 days) of Morus laevigata. Silva et al (2003b) reported that at the in vitro establishment phase, BA gave the highest in vitro multiplication rate of Prunus persica L. Batsch cv. Capdeboscq rootstocks, with 25.9 shoots/explant at 1.5 $\mathrm{mg} / \mathrm{litre}$. Yonemitsu et al (2003) mentioned that winter buds taken from mature trees of Japanese apricot (Prunus mume) were successfully established in culture on woody plant (WP) agar medium supplemented with $4.4 \mu \mathrm{M}$ (1 ppm) benzyladenine. The efficiencies of development of the bud into normal shoots were 50 to $100 \%$.

However, Bertsouklis et al (2003) mentioned that one-hundred percent of the node explants excised from two-month old seedlings of Globularia alypum gave 2 shoots per explant when cultured on solid MS medium without plant growth regulators.

\section{Experiment 2. Effect of heel:}

3 - Effect of heel on shoot number of Conocarpus erectus (Table 3 )

Leaving a heel on the explant was significantly superior in increasing shoot number of Conocarpus erectus. Number of shoots (produced 1 month after inoculation) in the presence of heel was 12.08, while explants taken without heels produced 1.75 shoots only.

Table (3) Effect of the heel on shoot number of Conocarpus erectus

\begin{tabular}{cc}
\hline Treatment & Shoot number \\
\hline With a heel & $12.08 \mathrm{a}$ \\
Without a heel & $1.75 \mathrm{~b}$ \\
\hline LSD at $5 \%$ & 1.41 \\
\hline
\end{tabular}

Beura et al (2003) mentioned that axillary bud with a piece of corm tissue (a heal) was excised from the harvested dormant corm of gladiolus cv. American Beauty plants and used as the initial explant.

4- Effect of heel on shoot length of Conocarpus erectus (Table 4)

No significant effect was remarked for heel on shoot length. Shoot length of explants with a heel was $0.52 \mathrm{~cm}$, while that of explants without a heel was 0.58 $\mathrm{cm}$.

Table (4) Effect of the heel on shoot length of Conocarpus erectus

\begin{tabular}{cc}
\hline Treatment & Shoot length \\
\hline With a heel & $0.52 \mathrm{a}$ \\
Without a heel & $0.58 \mathrm{a}$ \\
\hline LSD at $5 \%$ & NS \\
\hline
\end{tabular}

5 - Effect of heel on shoot fresh weight of Conocarpus erectus (Table 5)

Leaving a heel attached to the Conocarpus explants exerted a significant influence on shoot fresh weight. Without a heel, shoots were $0.08 \mathrm{~g}$, while those with heels were $0.32 \mathrm{~g}$.

Fayoum J. Agric. Res. \& Dev., Vol.19, No.1, January, 2005 
Mahmoud El Sayed Hashem; et al.,

Table (5) Effect of the heel on shoot fresh weight of Conocarpus erectus

\begin{tabular}{cc}
\hline Treatment & Shoot fresh weight \\
\hline With a heel & $0.32 \mathrm{a}$ \\
Without a heel & $0.08 \mathrm{~b}$ \\
\hline LSD at $5 \%$ & 0.06 \\
\hline
\end{tabular}

6 - Effect of heel on leaf number of Conocarpus erectus (Table 6)

The presence of heel influenced leaf number of Conocarpus erectus significantly. Number of leaves/shoot of explant with heels reached 41.60, while that of explants deprived of a heel was 7.92.

Table (6) Effect of the heel on leaf number of Conocarpus erectus

\begin{tabular}{cc}
\hline Treatment & Leaf number \\
\hline With a heel & $41.60 \mathrm{a}$ \\
Without a heel & $7.92 \mathrm{~b}$ \\
\hline LSD at $5 \%$ & 5.85 \\
\hline
\end{tabular}

Effect of the two cytokinins used on multiplication

Experiment 3. Effect of cytokinin type and concentration on multiplication.

7-1- Effect of cytokinin type and concentration on shoot fresh weight (g) of Cupressus macrocarpa (Table 7-1)

No significant difference was observed between BA and Kin in their effect on shoot fresh weight. With BA, shoot fresh weight was $0.18 \mathrm{~g}$, while that with Kin was $0.20 \mathrm{~g}$.

The effect of cytokinin concentration on shoot fresh weight was insignificant. Fresh weights recorded were $0.16,0.20$ and $0.20 \mathrm{~g}$ at 2,4 and $6 \mathrm{ppm}$.

Trend of the data representing the effect of both BA and Kin was almost opposite. Consequently, there was a statistically significant interaction between cytokinin type and concentration in their effect on shoot fresh weight of Cupressus macrocarpa explants. As BA concentration increased from 2 to 4 ppm, shoot fresh weight increased significantly from 0.17 to $0.23 \mathrm{~g}$. Further increase to $6 \mathrm{ppm}$ resulted in a significant deterioration in weight to become 0.14 g. Situation with Kin was not the same. As Kin concentration increased progressively from 2 to 4 and further to $6 \mathrm{ppm}$, fresh weight increased, though insignificantly from 0.16 to $0.17 \mathrm{~g}$, then significantly to $0.26 \mathrm{~g}$. In general, the heaviest shoots $(0.26 \mathrm{~g})$ were a result of using Kin at $6 \mathrm{ppm}$, lightest ones $(0.14$ g) were those grown on media supplemented with BA at $6 \mathrm{ppm}$.

Table (7-1) Effect of cytokinin type and concentration on shoot fresh weight (g) of Cupressus macrocarpa

\begin{tabular}{|c|c|c|c|}
\hline & \multicolumn{3}{|c|}{ Cytokinin Type } \\
\hline Cytokinin conc. (ppm) & BA & Kin & Mean \\
\hline 2 & $0.17 \mathrm{c}$ & $0.16 \mathrm{c}$ & 0.16 a \\
\hline 4 & $0.23 \mathrm{ab}$ & $0.17 \mathrm{bc}$ & $0.20 \mathrm{a}$ \\
\hline 6 & $0.14 \mathrm{c}$ & $0.26 \mathrm{a}$ & $0.20 \mathrm{a}$ \\
\hline Mean & 0.18 a & $0.20 \mathrm{a}$ & \\
\hline L.S.D. of Cytokinin type & NS & & \\
\hline L.S.D. of Cytokinin conc. & NS & & \\
\hline L.S.D. of Int. type $x$ conc. & 0.06 & & \\
\hline
\end{tabular}

L.S.D. at $5 \%$

Fayoum J. Agric. Res. \& Dev., Vol.19, No.1, January, 2005 
7-2- Effect of BA on shoot fresh weight (g) of Conocarpus erectus (Table 7-2)

As Conocarpus erectus explants did not respond to kinetin (Kin) treatments, results were confined to benzyladenine (BA) only.

When the BA concentration increased from 2 to $4 \mathrm{ppm}$, shoot fresh weight rose significantly from 0.18 to $0.32 \mathrm{~g}$, respectively. Further increase in BA level to $6 \mathrm{ppm}$ brought this record to a statistically significant decline, i.e. $0.08 \mathrm{~g}$.

Table (7-2) Effect of BA on shoot fresh weight (g) of Conocarpus erectus

\begin{tabular}{cc}
\hline BA conc. $(\mathrm{ppm})$ & Shoot fresh weight $(\mathrm{g})$ \\
\hline 2 & $0.18 \mathrm{~b}$ \\
4 & $0.32 \mathrm{a}$ \\
6 & $0.08 \mathrm{c}$ \\
\hline L.S.D. at $5 \%$ & 0.06 \\
\hline
\end{tabular}

The effect BA on shoot fresh weight was found by many authors to be true. Brum et al (2002) reported that the highest values for fresh matter weights of aerial parts of fig (Ficus carica) were obtained in the culture media supplemented with BAP at $2.0 \mathrm{mg} / \mathrm{litre}$. Silva et al (2002) stated that shoot fresh matter content of pineapple cv. Primavera was highest with $1.68 \mathrm{mg} \mathrm{BAP/litre.}$ Lucchesini et al (2003) found that good fresh weight of Passiflora incarnata was achieved using LS medium with $0.25 \mathrm{mg} \mathrm{BA} /$ litre.

\section{8-1- Effect of cytokinin type and concentration on shoot number of Cupressus macrocarpa (Table 8-1)}

a- The two types of cytokinins used, BA and Kin, differed significantly in their effect on shoot number of Cupressus macrocarpa explants. Incorporating $\mathrm{BA}$ in the multiplication media resulted in 17.18 shoots. Corresponding record with Kin was 7.28 shoots only.

b- Concentration of cytokinins used affected shoot number of Cupressus macrocarpa significantly. Difference between shoot number at 2 ppm (13.77) and at $4 \mathrm{ppm}$ (13.46) was statistically not significant. However, by raising the concentration used to $6 \mathrm{ppm}$, this number decreased significantly to 9.46 .

c- The interaction between effect of type and concentration of cytokinins was found to be statistically significant. As the BA concentration increased from 2 to 4 and $6 \mathrm{ppm}$, shoot number of Cupressus macrocarpa decreased significantly from 24.29 to 20.25 and finally to 7.00 shoots, respectively. On the contrary, the trend of Kin effect was an opposite one. The more the Kin concentration increased from 2 to 4 and $6 \mathrm{ppm}$, this number increased, first insignificantly from 3.25 to 6.67 , then significantly to 11.92 shoots, respectively. Highest shoot number (24.29 shoots) belonged to the BA at $2 \mathrm{ppm}$ treatment, while the lowest one (3.25 shoots) was a result of using Kin at $2 \mathrm{ppm}$. 
Table (8-1) Effect of cytokinin type and concentration on shoot number of Cupressus macrocarpa

\begin{tabular}{cccc}
\hline & Cytokinin & Type & \\
\hline Cytokinin conc. $(\mathrm{ppm})$ & BA & Kin & Mean \\
\hline 2 & $24.29 \mathrm{a}$ & $3.25 \mathrm{e}$ & $\mathbf{1 3 . 7 7} \mathbf{~ a}$ \\
4 & $20.25 \mathrm{~b}$ & $6.67 \mathrm{de}$ & $\mathbf{1 3 . 4 6 ~ a}$ \\
6 & $7.00 \mathrm{~d}$ & $11.92 \mathrm{c}$ & $\mathbf{9 . 4 6} \mathbf{~ b}$ \\
Mean & $\mathbf{1 7 . 1 8} \mathbf{~ a}$ & $\mathbf{7 . 2 8} \mathbf{~ b}$ & \\
\hline L.S.D.at 5\% of Cytokinin type & 2.04 & & \\
L.S.D.at 5\% of Cytokinin conc. & 2.49 & & \\
L.S.D.at 5\% of Int. type x conc. & 3.53 & & \\
\hline
\end{tabular}

8-2- Effect of BA on shoot number of Conocarpus erectus (Table 8-2)

The effect of BA concentrations on shoot number of Conocarpus erectus was significant. BA at $2 \mathrm{ppm}$ resulted in 5.17 shoots. This number increased significantly to 13.04 shoots by raising BA level to $4 \mathrm{ppm}$. However, this record declined significantly to 1.46 shoots only, by the ultimate rise in BA concentration to $6 \mathrm{ppm}$.

Table (8-2) Effect of BA on shoot number of Conocarpus erectus

\begin{tabular}{cc}
\hline BA conc. $(\mathrm{ppm})$ & Shoot number \\
\hline 2 & $5.17 \mathrm{~b}$ \\
6 & $13.04 \mathrm{a}$ \\
6 & $1.46 \mathrm{c}$ \\
\hline L.S.D. at $5 \%$ & 1.82 \\
\hline
\end{tabular}

The type of cytokinin used in the tissue culture media have a certain effect on the number of shoots produced in vitro. Giusti et al (2002) tested the feasibility of in vitro culture techniques for the propagation of the three endangered cacti species Escobaria minima, Mammillaria pectinifera and Pelecyphora aselliformis. A high multiplication rate combined with good quality proliferated shoots was observed on MS medium containing BA for E. minima and $M$. pectinifera and or kinetin for $P$. aselliformis. Aloufa et al (2003) mentioned that the best cytokinin for shoot multiplication of Ximenia americana (Fam. Oleaceae) was BA.

Cytokinin concentration can affect shoot number to a great extent. Capuana et al (1991) stated that in vitro bud proliferation of shoot explants of Cupressus sempervirens was detected on cytokinin-containing media. The concentration of different cytokinins (benzyladenine, kinetin) significantly affected bud proliferation. Chinsuk and Silayoi (2001) mentioned that explants of Musa acuminata cv. Kluai Bep cultured in MS media proliferated faster with increasing concentrations of benzyladenine (BA). Aloufa et al (2003) cultured single node explants of Ximenia americana in MS medium containing 2.5-15.0 $\mu \mathrm{M}$ (approx. 0.5-3.0 ppm) of BA or kinetin. They stated that the number of shoots per explant increased with the increase in the level of cytokinins.

A lot of workers remarked the interaction between type and concentration of the cytokinin used, as the effect of a certain cytokinin at a certain concentration determines the magnitude of the influence exerted on the number of shoots. Cytokinins used at $2 \mathrm{ppm}$ affected the multiplication stage in vitro. Baig and Shahzad (2003) mentioned that on MS medium with $2 \mathrm{mg}$ Kin/litre, direct shoot

Fayoum J. Agric. Res. \& Dev., Vol.19, No.1, January, 2005 
regeneration started from the cut end and from the tip region of shoots of Vernonia cinerea. Bhalla and Mulwa (2003) ascertained that inclusion of $2 \mathrm{mg}$ benzyladenine/litre in the medium produced the highest shoot number per single node segment explants of macadamia (Macadamia tetraphylla cv. Johnson). Kumar et al (2003) found that explants of marigold plants subcultured on MS medium supplemented with $2 \mathrm{mg}$ BA/litre gave maximum axillary bud sprouting compared with the other cytokinins, namely kinetin and thidiazuron. Sedlak and Paprstein (2003) working on pear (Pyrus communis) cv. Koporecka (Fam. Rosaceae) mentioned that the highest proliferation rate (5.6) was obtained on MS medium containing $2 \mathrm{mg} \mathrm{BA} / \mathrm{l}$. Singh $\boldsymbol{e t}$ al (2003) stated that a multiplication rate of 16-18 shoots was achieved for explants of Petunia hybrida nana compacta on MS medium supplemented with $2 \mathrm{mg}$ BA/litre. Thomas et al (2003) stated that woody plant medium with $2 \mathrm{mg} /$ litre BA (benzyladenine) produced maximum shoots from explants of Terminalia arjuna. Benniamin et al (2004) stated that nodal segments of Crateva magna (Fam. Capparidaceae) cultured in MS medium supplemented with 8.8 micro M (2 ppm) BAP produced multiple shoots $(4.4 \pm 0.09)$. Giridhar and Ravishankar (2004) claimed that transfer of bulbous shoot buds of Vanilla planifolia (Fam. Orchidaceae) onto the shoot proliferation medium supplemented with BA at 8.87 micro $\mathrm{M}$ (2 ppm) resulted in multiple shoot proliferation $(17 \pm 2.5$ shoots $)$.

The use of cytokinins at $4 \mathrm{ppm}$ was also reported. Beura et al (2003) mentioned that MS medium containing $4 \mathrm{mg}$ BAP/litre gave the greatest number of shoots (247.11 and 104.0) from single elongated buds of Gladiolus cv. American Beauty. Prashanta et al (2003) found that highest number of shoots (4.1) was proliferated from nodal explants of Syzygium jambos on MS medium with BAP at $4 \mathrm{mg} / \mathrm{litre}$.

Explants of some plants respond to a relatively higher concentration of cytokinins. Sebastian et al (2002) mentioned that maximum number of Rotula aquatica (Fam. Boraginaceae) shoots $(11.2 \pm 0.38)$ was developed in woody plant medium fortified with $6 \mathrm{mg} \mathrm{BA} / \mathrm{l}$.

On the other hand, cytokinins sometimes either have no effect or have a deleterious influence on shoot number. Fossi et al (1981) reported that kinetin at $1 \mathrm{ppm}$ did not stimulate bud development of Cupressus sempervirens explants. Baig and Shahzad (2003) mentioned that increasing Kin concentration to 5 $\mathrm{mg} / \mathrm{litre}$ decreased the morphogenic potential of Vernonia cinerea. Baig et al (2003) stated that an increase in Kin concentration to $5 \mathrm{mg} / \mathrm{litre}$ in MS media decreased the frequency of differentiation of Bacopa monniera. MS medium with $2 \mathrm{mg} \mathrm{BA}$ /itre inhibited differentiation, while $5 \mathrm{mg}$ BA/litre induced nodular green structures from the pith.

9-1- Effect of cytokinin type and concentration on shoot length of Cupressus macrocarpa (Table 9-1)

a- Length of Cupressus macrocarpa shoots grown in media supplemented with Kin was $0.36 \mathrm{~cm}$. Media enriched with BA gave significantly shorter shoots, i.e. $0.21 \mathrm{~cm}$ long.

b- The lowest cytokinin concentration, i.e. $2 \mathrm{ppm}$ gave rise to the significantly longest shoots, i.e. $0.35 \mathrm{~cm}$ long. Higher concentrations (4 and 6 $\mathrm{ppm})$ resulted in shorter shoots $(0.26$ and $0.25 \mathrm{~cm}$ long) without significant differences between them.

Fayoum J. Agric. Res. \& Dev., Vol.19, No.1, January, 2005 
c- As the trend of the data representing the effect of BA and that of Kin on shoot length of Cupressus macrocarpa was somewhat similar, the interaction between cytokinin type and concentration was statistically insignificant. However, shortest shoots $(0.19 \mathrm{~cm})$ were a result of using BA at $4 \mathrm{ppm}$. Applying Kin at $2 \mathrm{ppm}$ gave rise to the longest shoots $(0.48 \mathrm{~cm})$.

Table (9-1) Effect of cytokinin type and concentration on shoot length $(\mathrm{cm})$ of Cupressus macrocarpa

\begin{tabular}{cccc}
\hline & Cytokinin & Type & \\
\hline Cytokinin conc. $(\mathrm{ppm})$ & BA & Kin & Mean \\
\hline 2 & $0.23 \mathrm{bc}$ & $0.48 \mathrm{a}$ & $\mathbf{0 . 3 5} \mathbf{~ a}$ \\
4 & $0.19 \mathrm{c}$ & $0.33 \mathrm{~b}$ & $\mathbf{0 . 2 6} \mathbf{~ b}$ \\
6 & $0.22 \mathrm{c}$ & $0.28 \mathrm{bc}$ & $\mathbf{0 . 2 5} \mathbf{~ b}$ \\
Mean & $\mathbf{0 . 2 1} \mathbf{~ b}$ & $\mathbf{0 . 3 6 ~ a}$ & \\
\hline L.S.D.at 5\% of Cytokinin type & 0.06 & & \\
L.S.D.at 5\% of Cytokinin conc. & 0.08 & & \\
L.S.D.at 5\% of Int. type x conc. & NS & & \\
\hline
\end{tabular}

9-2- Effect of BA on shoot length (cm) of Conocarpus erectus (Table 9-2)

When BA concentrations increased from $2 \mathrm{ppm}$ to $4 \mathrm{ppm}$, shoot length increased, though insignificantly from $0.54 \mathrm{~cm}$ to $0.56 \mathrm{~cm}$. At the highest level used of BA $(6 \mathrm{ppm})$, shoot length decreased significantly to $0.36 \mathrm{~cm}$.

Table (9-2) Effect of BA on shoot length (cm) of Conocarpus erectus

\begin{tabular}{cc}
\hline BA conc. $(\mathrm{ppm})$ & Shoot length $(\mathrm{cm})$ \\
\hline 2 & $0.54 \mathrm{a}$ \\
4 & $0.56 \mathrm{a}$ \\
6 & $0.36 \mathrm{~b}$ \\
\hline L.S.D. at $5 \%$ & 0.14 \\
\hline
\end{tabular}

The effect of cytokinins on shoot length varies according to the type of cytokinin. Sudhakaran and Sivasankari (2003) mentioned that shoots of Ocimum basilicum (Fam. Lamiaceae) were longer in kinetin-supplemented media whereas BAP-supplemented media showed reduced shoot length.

Concentration of the cytokinin used has a great influence on shoot length. Zhu et al (2003) showed that length of the apple rootstock M26 shoot explants decreased with an increase in the concentration of benzyladenine (and IBA) in the multiplication medium. Similar results were obtained with the addition of kinetin in the elongation medium.

Each type of cytokinin at a certain concentration exerts a unique effect on length of shoots. The concentration of $2 \mathrm{ppm}$ was used by several researchers. Brum et al (2002) stated that the highest values for the lengths of aerial parts of fig (Ficus carica) were obtained in the culture media supplemented with BAP at $2.0 \mathrm{mg} / \mathrm{litre}$. Baig and Shahzad (2003) claimed that on $\mathrm{MS}+2 \mathrm{mg}$ BAP/litre medium, shoot tip elongation of Vernonia cinerea was observed. Bhalla and Mulwa (2003) stated that inclusion of $2 \mathrm{mg} \mathrm{BA} /$ litre in the medium produced the highest shoot length of macadamia (Macadamia tetraphylla cv. Johnson) a highly valued nut tree crop. Silva et al (2003b) stated that the different cytokinins (kinetin and BAP at 0.1-2.0 mg/litre) did not result in differences in shoot height of Prunus 'Capdeboscq' rootstocks. Benniamin et al (2004) stated

Fayoum J. Agric. Res. \& Dev., Vol.19, No.1, January, 2005 
that nodal segments of Crateva magna (Fam. Capparidaceae) cultured in MS medium supplemented with 8.8 micro M (2 ppm) BAP produced multiple shoots with the greatest length $(63.2+0.92 \mathrm{~mm})$.

The application of higher levels of cytokinins was also reported. Beura et al (2003) mentioned that MS medium containing $4 \mathrm{mg}$ BAP/litre gave the greatest shoot length $(8.9$ and $9.6 \mathrm{~cm})$ from single elongated buds of Gladiolus cv. American Beauty.

Baig and Shahzad (2003) reported that increasing Kin concentration in MS medium to $5 \mathrm{mg} / \mathrm{litre}$ resulted in shoot tip elongation of Vernonia cinerea, Scrophulariaceae, while MS medium with $5 \mathrm{mg}$ BAP/litre gave rise to compact, green nodular callusing. Giridhar et al (2003) stated that the longest shoot length of Decalepis hamiltonii was obtained on medium containing 5 ppm BA (and 2 ppm phenylacetic acid). Silva et al (2003a) cultured shoot apices and lateral buds of 3 rootstocks of Prunus on Lepoivre medium supplemented with $5.0 \mathrm{mg}$ BAP/litre. They stated that shoots were produced with average heights of 7.8-9.3 mm.

On the other hand, a negative effect of cytokinins was reported by some authors. Karasawa et al (2002) claimed that the best plantlet height of three cultivars of elephant grass (Pennisetum purpureum) was obtained in liquid and solid medium without benzyladenine. Bhalla and Mulwa (2003) stated that levels above $2 \mathrm{mg}$ BA/litre in the medium produced stunted shoots of macadamia (Macadamia tetraphylla $\mathrm{cv}$. Johnson).

10 - Effect of BA on total leaf number of Conocarpus erectus (Table 10).

As leaves of Cupressus macrocarpa are very minute and difficult to count, leaf number was recorded and analyzed for Conocarpus erectus only. Total leaf number responded significantly to BA concentrations. At $2 \mathrm{ppm}$ of BA this number was 22.08 leaves. A significant increase of more than twofold occurred when BA at 4 ppm was applied. However, further increase in BA concentration to $6 \mathrm{ppm}$ proved detrimental, as a statistically significant drop in this reespect to 2.08 was recorded.

In this concern, Nagaraju and Mani (2003) concluderd that supplementation of BA $(0.5-2.0 \mathrm{mg} / \mathrm{litre})$ in the media increased leaf number of Cymbidium Lunavian Atlas explants (Fam. Orchidaceae). Prashanta et al (2003) reported that maximum leaf number (5.0) was proliferated from nodal explants of Syzygium jambos on MS medium with BAP (benzyladenine) at $4 \mathrm{mg} / \mathrm{litre}$.

Table (10) Effect of BA on total leaf number of Conocarpus erectus

\begin{tabular}{cc}
\hline BA conc. $(\mathrm{ppm})$ & Total leaf number \\
\hline 2 & $22.08 \mathrm{~b}$ \\
4 & $45.04 \mathrm{a}$ \\
6 & $2.08 \mathrm{c}$ \\
\hline L.S.D. at $5 \%$ & 5.49 \\
\hline
\end{tabular}

11-1- Effect of cytokinin type and concentration on total chlorophyll content (mg/g fresh weight) of Cupressus macrocarpa shoots (Table 11-1).

a - Total chlorophyll content of Cupressus macrocarpa shoots was greater in case of Kin application $(1.13 \mathrm{mg} / \mathrm{g}$ fresh weight) than when BA was used $(0.69$ $\mathrm{mg} / \mathrm{g}$ fresh weight).

Fayoum J. Agric. Res. \& Dev., Vol.19, No.1, January, 2005 
$\mathrm{b}$ - As the concentration of cytokinins used increased (2, 4 and $6 \mathrm{ppm})$, this record increased progressively $(0.47,0.80$ and $1.47 \mathrm{mg} / \mathrm{g}$ fresh weight, respectively).

$\mathrm{c}$ - The effect of BA and that of Kin concentration was somewhat similar. As concentrations of both BA and Kin increased from 2 to 4 and finally to $6 \mathrm{ppm}$, this content increased steadily from 0.38 to 0.50 and $1.20 \mathrm{mg} / \mathrm{g}$ fresh weight for $\mathrm{BA}$, and from 0.56 to 1.10 and $1.73 \mathrm{mg} / \mathrm{g}$ fresh weight for Kin, respectively.

Table (11-1) Effect of cytokinin type and concentration on total chlorophyll content (mg/g fresh weight) of Cupressus macrocarpa shoots

\begin{tabular}{cccc}
\hline & \multicolumn{4}{l}{ Cytokinin type } & \\
\hline Cytokinin conc. $(\mathrm{ppm})$ & BA & Kin & Mean \\
\hline 2 & 0.38 & 0.56 & $\mathbf{0 . 4 7}$ \\
6 & 0.50 & 1.10 & $\mathbf{0 . 8 0}$ \\
Mean & 1.20 & 1.73 & $\mathbf{1 . 4 7}$ \\
\hline
\end{tabular}

11-2- Effect of BA on total chlorophyll content (mg/g fresh weight) of Conocarpus erectus shoots (Table 11-2).

Total chlorophyll content responded positively to the increase in BA concentration. However, this response was to a little extent, from 1.19 to 1.32 $\mathrm{mg} / \mathrm{g}$ fresh weight as the concentration of BA was raised from 2 to $4 \mathrm{ppm}$. The second increase in BA level to $6 \mathrm{ppm}$ was associated with a greater increase in this content to $3.93 \mathrm{mg} / \mathrm{g}$ fresh weight.

Table (11-2) Effect of BA on total chlorophyll content (mg/g fresh weight) of Conocarpus erectus shoots

\begin{tabular}{cc}
\hline BA conc. $(\mathrm{ppm})$ & Total chlorophyll content $(\mathrm{mg} / \mathrm{g}$ fresh weight $)$ \\
\hline 2 & 1.19 \\
4 & 1.32 \\
6 & 3.93 \\
\hline
\end{tabular}

The relation between chlorophyll content and cytokinin application was studied by a lot of workers. Gusev et al (1989) remarked that reducing the BA concentration in MS medium increased the contents of chlorophylls a and b in explants of both Ficus elastica and Scorzonera spp. (Fam. Asteraceae). Saadawy (2000) working on two orchid species found that the highest content of total chlorophyll was achieved by incorporating BA in MS multiplcation medium at 1 ppm for Laelia anceps or at $5 \mathrm{ppm}$ for Cymbidium devonianum. Singh and Syamal (2001) found that total leaf chlorophyll $(a+b)$ content of hybrid tea rose (Rosa hybrida, Fam. Rosaceae) cultivars Sonia and Raktagandha, increased in shoots regenerated on normal proliferation medium (PM) containing 2 ppm BA (in addition to $0.1 \mathrm{ppm}$ NAA and $0.1 \mathrm{ppm}$ gibberellic acid (GA3). AbdelRahman (2002) stated that using BA at $0.5 \mathrm{ppm}$ in MS medium tends, in general, to reduce (though insignificantly in most cases) chlorophyll $a$ and $b$ compared to the untreated explants of two Solidago (Fam. Asteraceae) cultivars (Toto and Tara). Kapchina-Toteva and Stoyanova (2003) mentioned that chlorophyll a and b contents in the shoots of Gypsophila paniculata decreased with the addition of cytokinins in the culture medium. Yagisawa et al (2003) examined chloroplast replication in leaf disks from Brassica rapa var. perviridis (B. campestris var. rapa, Fam. Brassicaceae) in culture media with and without

Fayoum J. Agric. Res. \& Dev., Vol.19, No.1, January, 2005 
benzyladenine. They found that the number of chloroplasts per cell increased from about 18 to 300 without benzyladenine, and to over 600 with benzyladenine, indicating that this cytokinin enhances chloroplast replication in cultured tissue. El-Malt and Saadawy (2005) stated that Paulownia tomentosa (Fam. Scrophulariaceae) shoot content of chlorophyll a increased dramatically compared to the control treatment when BA was applied at $2.5 \mathrm{ppm}$. The next increase in BA concentration to $5 \mathrm{ppm}$ yielded an unremarkable increase in the aforementioned content. Higher doses of BA, i.e. 7.5 and $10 \mathrm{ppm}$, resulted in great deterioration in this character. Shoots grown on media supplemented with $\mathrm{BA}$ at $5 \mathrm{ppm}$ had the highest content of chlorophyll b. Other concentrations of BA resulted in a very low content compared to $5 \mathrm{ppm}$.

12-1- Effect of cytokinin type and concentration on carotenoids content (mg/g fresh weight) of Cupressus macrocarpa shoots (Table 12-1).

a- The effect of cytokinin type on carotenoids content of Cupressus macrocarpa shoots was similar to the corresponding effect on total chlorophyll content. Kin-treated shoots had larger content of carotenoids $(0.34 \mathrm{mg} / \mathrm{g}$ fresh weight) compared to that of BA-treated ones, which had $0.27 \mathrm{mg} / \mathrm{g}$ fresh weight.

b-Cytokinin concentration exerted a similar influence on carotenoids content as mentioned before on chlorophyll. As the cytokinin concentration increased, carotenoids content increased from 0.20 to 0.33 and finally to $0.38 \mathrm{mg} / \mathrm{g}$ fresh weight for 2, 4 and $6 \mathrm{ppm}$, respectively.

c- BA and Kin effects on carotenoids content were identical at 2 and 4 ppm (0.20 and $0.33 \mathrm{mg} / \mathrm{g}$ fresh weight, respectively). However, at the highest level used $(6 \mathrm{ppm})$, this content dropped to $0.28 \mathrm{mg} / \mathrm{g}$ fresh weight with BA. On the contrary, the highest level used of Kin $(6 \mathrm{ppm})$ resulted in the highest content of carotenoids $(0.49 \mathrm{mg} / \mathrm{g}$ fresh weight).

Table (12-1) Effect of cytokinin type and concentration on carotenoids content (mg/g fresh weight) of Cupressus macrocarpa shoots

\begin{tabular}{cccc}
\hline & Cytokinin & type & \\
\hline Cytokinin conc. $(\mathrm{ppm})$ & BA & Kin & Mean \\
\hline 2 & 0.20 & 0.20 & $\mathbf{0 . 2 0}$ \\
4 & 0.33 & 0.33 & $\mathbf{0 . 3 3}$ \\
6 & 0.28 & 0.49 & $\mathbf{0 . 3 8}$ \\
\hline Mean & $\mathbf{0 . 2 7}$ & $\mathbf{0 . 3 4}$ & \\
\hline
\end{tabular}

12-2- Effect of BA on carotenoids content (mg/g fresh weight) of Conocarpus erectus shoots (Table 12-2)

Carotenoids content of Conocarpus erectus shoots increased from 0.42 to $0.62 \mathrm{mg} / \mathrm{g}$ fresh weight and further to $0.72 \mathrm{mg} / \mathrm{g}$ fresh weight as a result of the increase in BA level from 2 to 4 and finally to $6 \mathrm{ppm}$.

Table (12-2) Effect of BA on carotenoids content (mg/g fresh weight) of Conocarpus erectus shoots

\begin{tabular}{cc}
\hline BA conc. $(\mathrm{ppm})$ & Carotenoids content $(\mathrm{mg} / \mathrm{g}$ fresh weight) \\
\hline 2 & 0.42 \\
4 & 0.62 \\
6 & 0.72 \\
\hline
\end{tabular}

Fayoum J. Agric. Res. \& Dev., Vol.19, No.1, January, 2005 
Abdel-Rahman (2002) stated that using BA at $0.5 \mathrm{ppm}$ in MS medium tends, in general, to reduce (though insignificantly in most cases) carotenoid content compared to the untreated explants of two Solidago cultivars (Toto and Tara). El-Malt and Saadawy (2005) found that application of BA at $2.5 \mathrm{ppm}$ raised shoot content of carotenoids to the highest level. BA at $5 \mathrm{ppm}$ resulted in the next high level of this pigment in shoots of Paulownia tomentosa. Other concentrations of BA induced low contents. The lowest record was found in the control treatment i.e. no BA at all.

Therefore, it can be concluded that the use of BA at the establishment stage gave the highest multiplication rates of Cupressus macrocarpa and Conocarpus erectus, though the effect was insignificant with the first species. It is recommended to leave a heel (about $2 \mathrm{~mm}$ long) on the explant of Conocarpus erectus. Applying BA at 2 and $4 \mathrm{ppm}$ in the multiplication stage gave the highest number of Cupressus macrocarpa and Conocarpus erectus shoots, respectively.

\section{REFERENCES}

Abdel-Rahman, S. S. (2002). Physiological studies on the micropropagation of Solidago spp. By In vitro Culture. Ph. D. Thesis. Faculty of. Agric., Cairo Univ.

Aloufa, M. A. I.; S. M. L. Bezerra and G. P. T. Jordao (2003). In vitro clonal mass propagation of Ximenia americana L. Fruits (Paris), 58(3): 175178.

Baig, N.; M.A. Musharraf and A. Shahzad (2003). In vitro rapid multiplication of Bacopa monniera through nodal segment culture. Bionotes, 5(2): 39.

Baig, N. and A. Shahzad (2003). In vitro vegetative multiplication of Vernonia cinerea through shoot tip culture. Bionotes, 5(3):65.

Benniamin, A.; Manickam, V. S.; Johnson, M. and Joseph, L. H. (2004). Micropropagation of Crateva magna (Lour.) DC. - a medicinal plant. Indian Journal of Biotechnology, 3(1): 136-138.

Bertsouklis, K.; M. Papafotiou and G. Balotis (2003). Effect of medium on in vitro growth and ex vitro establishment of Globularia alypum L. Acta Hort., 616: 177-180.

Beura, S.; R. Singh and P. N. Jagadev (2003). In vitro shoot proliferation and corm production in gladiolus cultivar American Beauty. J. Ornament. Hort. (New Series), 6(3): 195-201.

Bhalla, P. L. and R. M. S. Mulwa (2003). Tissue culture and macadamia propagation. Acta Hort., 616: 343-346.

Brum, G. R.; A. B. da Silva and M. Pasqual (2002). Effect of different concentrations of BAP and ANA in the fig (Ficus carica L.) in vitro propagation. Ciencia e Agrotecnologia, 26 (Especial): 1403-1409.

Capuana, M. and R. Giannini (1997). Micropropagation of young and adult plants of cypress (Cupressus sempervirens L.). J. Hort. Sci., 72 (3): 453-460.

Capuana, M.; R. Giannini; M. Lambardi; A. R. Leva and F. P. Nicese (1991). Micropropagation of mature plants of cypress (Cupressus sempervirens L.). Acta Hort., 289:91-92.

Chinsuk, A. and B. Silayoi (2001). Effects of culture media and growing media on Kluai Bep. Kasetsart J., Natural Sci., 35 (4): 368-377.

Fayoum J. Agric. Res. \& Dev., Vol.19, No.1, January, 2005 
El-Malt, A. A. T. and F. M. Saadawy (2005). Studies on the propagation of Paulownia tomentosa trees. II-Effect of benzyladenine on the propagation by tissue culture. Egypt J. Appl. Sci.; 20 (2): 226-239.

Fossi, D.; P. M. di Lipucci and F. Tognoni (1981). In vitro induction of axillary buds in Cupressus sempervirens. Rivista della Ortoflorofrutticoltura Italiana, 65 (4): 293-299.

Franco, E. O. and O. J. Schwarz (1985). Micropropagation of two tropical conifers: Pinus oocarpa Schiede and Cupressus lusitanica Miller. Tissue culture in forestry and agriculture. Proceedings of the third Tennessee Symposium on Plant Cell and Tissue Culture held Sept. 913,1984 at the University of Tennessee, Knoxville:195-213.

GenLin, L.; L. XiaoChu; L. ZhenHai; N. JingDe; L. YuQiao and H. LiBin (2003). Techniques of tissue culture and in vitro clonal propagation of Ilex latifolia. Forest Research, Beijing, 16(4): 439-443.

Giridhar, P. and G. A. Ravishankar (2004). Efficient micropropagation of Vanilla planifolia Andr. under the influence of thidiazuron, zeatin and coconut milk. Indian Journal of Biotechnology, 3(1): 113-118.

Giridhar, P.; D. V. Ramu; B. O. Reddy; T. Rajasekaran and G. A. Ravishankar (2003). Influence of phenylacetic acid on clonal propagation of Decalepis hamiltonii Wight \& Arn: an endangered shrub. In vitro Cellular \& Develop. Biol. - Plant, 39(5): 463-467.

Giusti, P.; D. Vitti; F. Fiocchetti; G. Colla; F. Saccardo.; M. Tucci (2002). In vitro propagation of three endangered cactus species. Scientia Horticulturae, 95(4): 319-332.

Gusev, M. V.; E. N. Markarova; I. B. Kol'chugina; T. V. Kolganova and V. A. Veselovskii (1989). Chlorophyll content, photosynthesis and delayed light emission of the photoheterotrophic tissue culture of rubber-bearing plants. Fiziologiya i Biokhimiya Kul'turnykh Rastenii, 21 (4): 321-328.

Isutsa, D. K. (2004). Rapid micropropagation of passion fruit (Passiflora edulis Sims.) varieties. Scientia Horticulturae,99(3/4):395-400.

Kapchina-Toteva, V. and D. Stoyanova (2003). Effect of cytokinins and cytokinin antagonists on in vitro cultured Gypsophila paniculata L. Biologia Plantarum, 46(3):337-341.

Karasawa, M. M. G.; J. E. B. P. Pinto; J. C. Pinto and A. v. Pereira (2002). The influence of growth regulator and medium on proliferation of in vitro propagated elephant grass. Ciencia e Agrotecnologia, 26(6): 1243-1251.

Kumar, A.; S.P.S. Raghava; S. K. Singh and R. L. Misra (2003). In vitro culture initiation techniques from field-grown marigold plants. J. Ornam. Hort. (New Series), 6 (1): 7-10.

Lambardi, M.; I.S. Harry; D. Menabeni and T.A. Thorp (1995). Organogenesis and somatic embryogenesis in Cupressus sempervirens. Plant Cell, Tissue and Organ Culture, 40:179-182.

Lucchesini, M.; M. Mingozzi and A. Mensuali-Sodi (2003). Callus formation and shoot regeneration of Passiflora incarnata L. from seed explants. Agricoltura Mediterranea, 133 (1): 72-80.

Meghwal, P. R.; S. K. Singh and H. C. Sharma (2003). Micropropagation of Aneuploid guava. Indian J. Hort., 60 (1): 29-33.

Fayoum J. Agric. Res. \& Dev., Vol.19, No.1, January, 2005 
MeiChun, L. (2003). Tissue culture of Morus laevigata Wall using axillary buds. J. Chinese Soc. Hort. Sci., 49(3): 251-258.

Mishra, M. K. and H. L. Sreenath (2003). In vitro induction of adventitious shoot buds and plant regeneration from leaf explants of Coffea bengalensis Roxb.: a wild coffee species. Plant Cell Biotechnology and Molecular Biology, 4(1/2): 57-62.

Murashige, T. and F. Skoog (1962). A revised medium for rapid growth and bio-assay with tobacco tissue culture. Physiol. Plant. 15: 473-497.

Nagaraju, V. and S. K. Mani (2003). Influence of mercuric chloride and growth substances on culture initiation and multiplication of Gladiolus cv. Ice Gold in vitro. J. Hill Research, 16 (1): 45-48.

Ponchia, G and G. Zanin (2000). In vitro Propagation of Skimmia (Skimmia japonica Thunb.). Proc. XXV IHC. Acta Hort. 520 ISHS, 10:91-95.

Prashanta, K. G.; B. N. Sathyanarayana; D. Mathew and S. N. Sondur (2003). In vitro callus induction and plantlet regeneration in roseapple (Syzygium jambos L.). J. Plant Biol., 30(1): 99-102.

Saadawy, F. M. (2000). Studies on the propagation of some Ornamental plants by tissue culture. Ph. D. Thesis. Fac. Agric., Ain Shams Univ.

Sebastian, D. P.; S. Benjamin and M. Hariharan (2002). Micropropagation of Rotula aquatica Lour. - an important woody medicinal plant. Phytomorphology, 52 (2/3): 137-144.

Sedlak, J. and F. Paprstein (2003). Influence of growth regulators on in vitro propagation of Pyrus communis cv. Koporecka. Acta Hort., 616: 379382.

Silva, A. B. da; M. Pasqual; A. L. de R. Maciel; M. A. Moreira and L. F. Dutra (2002). Influence of benzylaminopurine and benomyl on in vitro pineapple proliferation. Ciencia e Agrotecnologia, 26 (6): 11901196.

Silva, A. L. da; M. Rogalski; L. K. A. de Moraes; C. Feslibino L. Crestani and M. P. Guerra (2003a). In vitro establishment and multiplication of Prunus rootstocks. Revista Brasileira de Fruticultura, 25(2): 297300.

Silva, A. L. da; M. Rogalski and M. P. Guerra (2003b). Effects of different cytokinins on in vitro multiplication of Prunus 'Capdeboscq' rootstocks. Crop Breeding and Applied Biotechnology, 3 (2): 149155.

Singh, S. K. and M. M. Syamal (2001). A short pre-culture soak in thidiazuron or forchlorfenuron improves axillary shoot proliferation in rose micropropagation. Scientia Horticulturae, 91 (1/2): 169-177.

Singh, S.; G. S. Virk and A. Nagpal (2003). Effect of growth regulators on plant regeneration from leaf derived callus in Petunia hybrida. Journal of Ornamental Horticulture (New Series), 6 (3): 239-243.

Snedecor, G. W. and W. G. Cochran (1980). Statistical Methods, $6^{\text {th }}$ ed., Iowa State Univ. Press, Iowa, USA.

Spanos, K. A.; A. Pirrie and S. Woodward, S. (1997). Micropropagation of Cupressus sempervirens L. and Chamaecyparis lawsoniana (A. Murr.) Par. Silvae Genetica, 46 (5): 291-295.

Fayoum J. Agric. Res. \& Dev., Vol.19, No.1, January, 2005 
Sudhakaran, S. and V. Sivasankari (2003). A protocol for in vitro plant regeneration in Ocimum basilicum L.: a medicinal herb. Plant Cell Biotechnology and Molecular Biology, 4 (3/4): 185-188.

Thomas, T.V.; A.B.R. Shree; E. Nabeesa; N. Neelakandan and S. Nandakumar (2003). In vitro propagation of Terminalia arjuna Roxb.: a multipurpose tree. Plant Cell Biotech. and Molecular Biol., 4(1/2): 95-98.

Yagisawa, F.; T. Mori; T. Higashiyama; H. Kuroiwa and T. Kuroiwa (2003). Regulation of Brassica rapa chloroplast proliferation in vivo and in cultured leaf disks. Protoplasma, 222 (3/4): 139-148.

Yonemitsu, H.; K. Nishi; S. Sagan; L. Tong and Y. Matsumura (2003). In vitro propagation of mature Japanese apricot (Prunus mume Sieb. et Zucc.). Hort. Research (Japan), 2(2): 77-82.

Zhu, L. H.; X. Y. Li and M. Welander (2003). Micropropagation of the apple rootstock M26 by temporary immersion system (TIS). Acta Hort., 616:365-368.

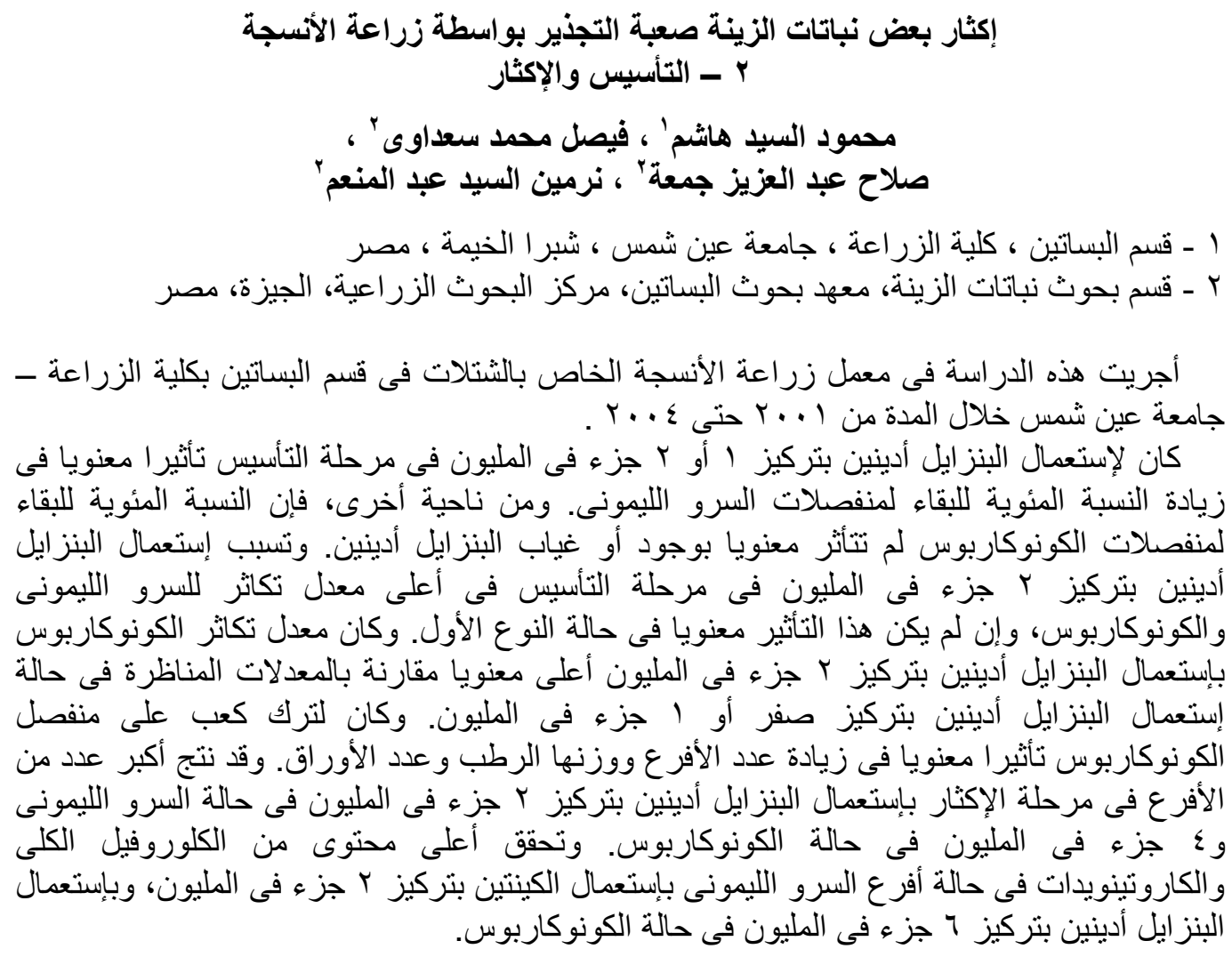

Fayoum J. Agric. Res. \& Dev., Vol.19, No.1, January, 2005 